\title{
The development of student worksheet assisted by interactive multimedia of photoelectric effect to build science process skills
}

\author{
Payudi, Chandra Ertikanto, Noor Fadiawati, Agus Suyatna \\ Physics Education Department of Graduate Program, Lampung University \\ Jalan Sumantri Brojonegoro No. 01, Gedong Meneng Rajabasa Kota Bandar Lampung \\ Lampung 35141 INDONESIA \\ E-mail:payudi70@gmail.com
}

\begin{abstract}
This research aims to produce student worksheet based on interactive multimedia on photoelectric effect to grow science process skills that are attractive, easy, useful, and study to improve students learning out comes. The development design used in this research by Sugiono which implemented in 8 stages, they are potential and problem, data collecting, product design, validation design, revision design, product trial, product, and trial usage. Trial usage of the product was conducted at SMA Negeri 2 Bandar Lampung in October 2016 to November 2016 and the research subject was twelve grade classes. The sampling technique of product trial subjects done by purpose sampling, it took two same classes. One class used as an experimental class and the other class as a control class. Trial product design used Matching-Only Pretest-Post test Control Group Design method. Data collecting technique used questionnaire and test (pretest and post test). The data were analyzed by using a descriptive quantitative method. The conclusions of the research are: (1) Student worksheet to build scientific process skills on photoelectric effect should include predicting and hypothesizing activities, planning the experiment, doing the practicum, interpreting the observation, and communicating. (2) Student worksheet of development result has an attractiveness level with the average score is 3.27 or $81.74 \%$ with "interesting" category, ease level with the average score is 3.25 or 81.32 with "simple", and usefulness level with the average score is 3.21 or $80.13 \%$ of "useful" category. (3) Student worksheet of development result is effective to improve students learning outcomes in science process skills with $\mathrm{N}$-gain average is 0.63 with the medium.
\end{abstract}

Keyword : interactive multimedia, photoelectric effect, science process skills

\section{Introduction}

The most important matter in physic learning is the active learners, while the teacher is expected to master the material to be taught, to understand the condition of them so that they can according to the circumstances and the development of themselves [1]. Furthermore, in physical learning, learners not only listen, record, and remember from the subject matter delivered by the teacher, but more emphasized on their ability to be able to solve the problem and act to the learned matter, then communicate the results [1]. 
Therefore, to meet the demands of physical learning's characteristics and objectives, it needs a developing student worksheet that can help students to understand the problems better and the phenomena they find in the natural environment. The student worksheet is a sheet containing work or materials that make students more active and can take meaning from the learning process [2].

One of the obstacles found in the photoelectric material learning process is that it is hard to visualize how the electrons escape from the metal surface when exposed to a certain light and the influence of other factors that accompany the electron's release. Although learning sources such as books, libraries, the Internet, etc. can search the photoelectric effect materials, the student worksheet that fit the characteristics of photoelectric effect learning have not been widely available. In fact, generally, the student worksheet that has been owned by learners so far has not been able to help in finding the concept, because it only contains material and problems. Furthermore, in regarding to presentation is less attractive [3].

Based on the results of the questionnaire analysis, the learning needs of photoelectric effect material is given to the students is known as much as $16.67 \%$ of students stated that in studying material such as photoelectric effect has been done a practicum. Meanwhile, based on the results given to the teacher is known as much as $33.33 \%$ of teachers has been done a practicum though only by way of demonstration using animation. The poor learning activity of photoelectric effect material using Practicum activity is due to the unavailability of practicum facilities and infrastructure to explain the photoelectric effect which means that it still dominated by the teacher with the way of the lecture. Due to the unavailability of Practicum tools to clarify the occurrence of the photoelectric effect, interactive multimedia is one option that can support the learning process.

Also, in the realities of education in the field, many teachers in schools still use the conventional or the monotonous student worksheet, that is wearable, instant, and without an effort to plan, prepare, and arrange itself [4]. Although teachers know and are aware that the student worksheet they don't often use, fits with the primary competencies and learning indicators to be achieved.

The materials, guidance questions, and tasks in the usual student worksheet are inconsistent and not contextual with the students' needs, so it can't improve students' competence [4]. Besides, student worksheet has been established to help improve students' ability in interpreting and explaining the objects learned, especially on science subjects. The aim of the established student worksheet happens because of the impact of self-development poverty from teachers so that teachers can't organize effective and efficient learning. This impact is one of the reasons why teachers are the lack of creativity to plan and prepare innovative student worksheet and the lack of ability to explore student ideas [4].

Also, for a long time, the student worksheet explanation with traditional learning models such as "practice-sample-sample-practice-examples" has been very easy for teachers, but for students, it has been tedious and difficult, so that it can affect students' 
learning outcomes [5]. Traditional learning models makes students unable to acquire new knowledge by themselves, and the learning process is ineffective and efficient.

Unavailability of facilities and infrastructures to explain the occurrence of the photoelectric effect, interactive multimedia is one option that can support the learning process. Physics Education of Technology (PhET) software is one of the software developed by the University of Colorado to help visualize the occurrence of photoelectric effects and the factors that accompany it. By using PhET, students can: observe the electrons out of the metal surface when exposed to a certain light, measure the maximum wavelength of a light that can remove electrons from the metal surface, measure the potential stopper for each light, and measure the magnitudes related with the event of the photoelectric effect. Students can also conclude that not all lights when hit the metal will result in a photoelectric effect or make other conclusions that cannot be explained by light as waves. So that with the interactive multimedia in the form of PhET software, it is expected in the learning of teachers to use the media that rich in visualization and teachers can make learning innovations. One of the innovations is by integrating information and communication technology in the form of interactive multimedia [6]. The use of technology PhET is more productive than traditional methods such as lectures and demonstrations [7].

The implementation of photoelectric effect material with the lab does not only rely on interactive multimedia in the form of PhET simulation but also the student worksheet that can optimize the interactive multimedia so that students can achieve the learning objectives to achieve. The implementation of the process skills supported by the adjusted student worksheet through an experiment of inquiry model activity which obtains the improvement of students' learning result [8]. The student worksheet with $\mathrm{PhET}$ virtual lab in the main discussion of kinetic gas theory is suitable to use in the learning [9].

Based on the above explanation, the purposes of this research are: (1) Developing the student worksheet assisted by interactive multimedia of photoelectric effect to grow science process skills; (2) Describing the attractiveness, difficulty, and usefulness of the student worksheet; (3) Describing the effectiveness level of the student worksheet in terms of student learning outcomes.Other paragraphs are indented (BodytextIndented style).

\section{Research Method}

The development design used in this research by Sugiono which implemented in 8 stages, they are potential and problem, data collecting, product design, validation design, revision design, product trial, product, and trial usage [10].

Trial usage of the product was conducted at SMA Negeri 2 Bandar Lampung in October 2016 to November 2016 and the research subject was twelve grade classes. The sampling technique of product trial subjects done by purpose sampling, it took two same classes. One class used as an experimental class and the other class as a control 
class. Trial product design used Matching-Only Pretest-Post test Control Group Design method. The effectiveness level of the product viewed from pretest and post test.

The collected data, then analyzed. Data processing of this research done by a statistical test, that is a prerequisite test in the form of normality test and homogeneity test. The difference test was used to test the significant effect of the student worksheet on the improvement of student science process skills. A normalized value analyzed by determining the effectivenes level of the product [11]. The N-gain score can be calculated using the following equation:

$<\mathrm{g}>=\{<\mathrm{Sf}>-<\mathrm{Si}>\} /\{100-<\mathrm{Si}>\}$

Information:

$<\mathrm{g}>=$ normalized gain

$<\mathrm{Sf}>=$ post test score

$<\mathrm{Si}>=$ pretest score

Classify the normalized gain as follows: (1) If the value of $g \geq 0.7$, then the resulting $\mathrm{N}$-gain belongs to the high category, (2) If $0.3 \leq \mathrm{g}<0.7$ belongs to the medium category, (3) If $g<0.3$ belongs to the low category.

\section{Results and Discussion}

Figure 1 shows the graphic of the average ratio of the science process skills pre test and post test values of the experimental class and control class.

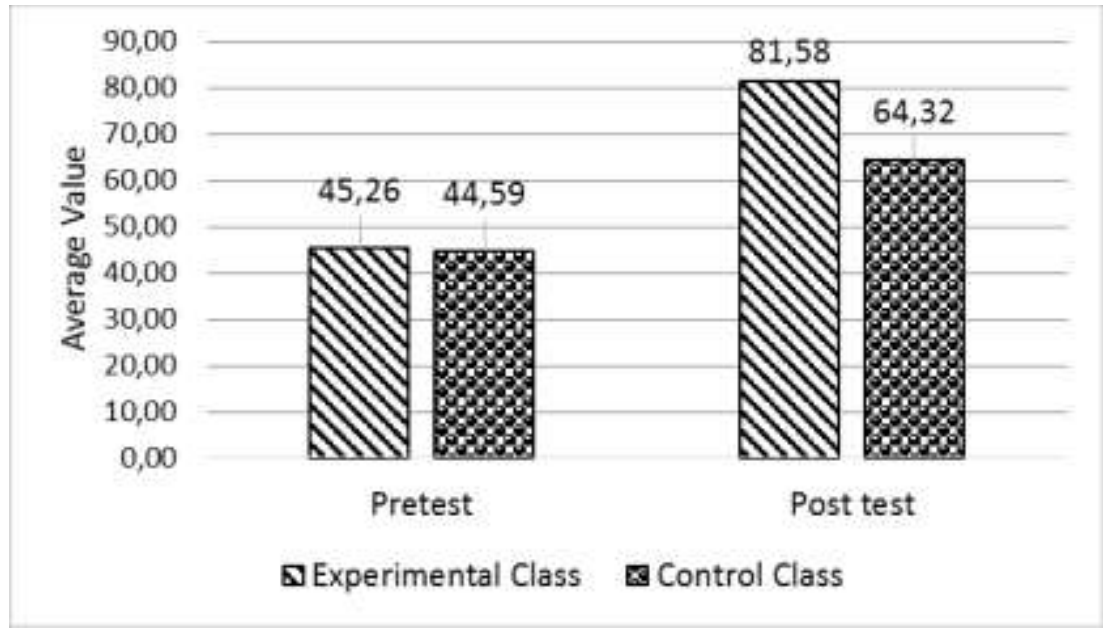

Figure 1. Shows the graphic of average Ratio of the Science Process Skills Pretest and Post test Values of the Experimental Class and Control Class.

Based on figure 1, it can be seen that the average pre test grade of experimental class and control class are 45.26 and 44.59 respectively. The difference test results show no significant difference between the pretest grade of the experimental class and the control class. When viewed from the pretest score obtained by the two small classes, this may be because in learning process has not emphasized the involvement of students and has not given concrete examples so that students can easily understand the complex and abstract concepts. It is one of the reasons underlying the need to apply science process 
skills. Science process skills emphasize students in the learning process [12]. Also, the low average pre test score obtained by the experimental class and the control class may also caused by the learning process that has not based on the science process skills to solve a problem. Science process skills have a big influence on science education because it helps students to develop higher mental skills, such as critical thinking, decision making, and problem-solving [13].

The photoelectric effect material learning uses the student worksheet in the experimental class is done by using some groups to follow the steps of the science process skills in the student worksheet. The following figures are the examples of one of the experimental groups' results in the learning activity.

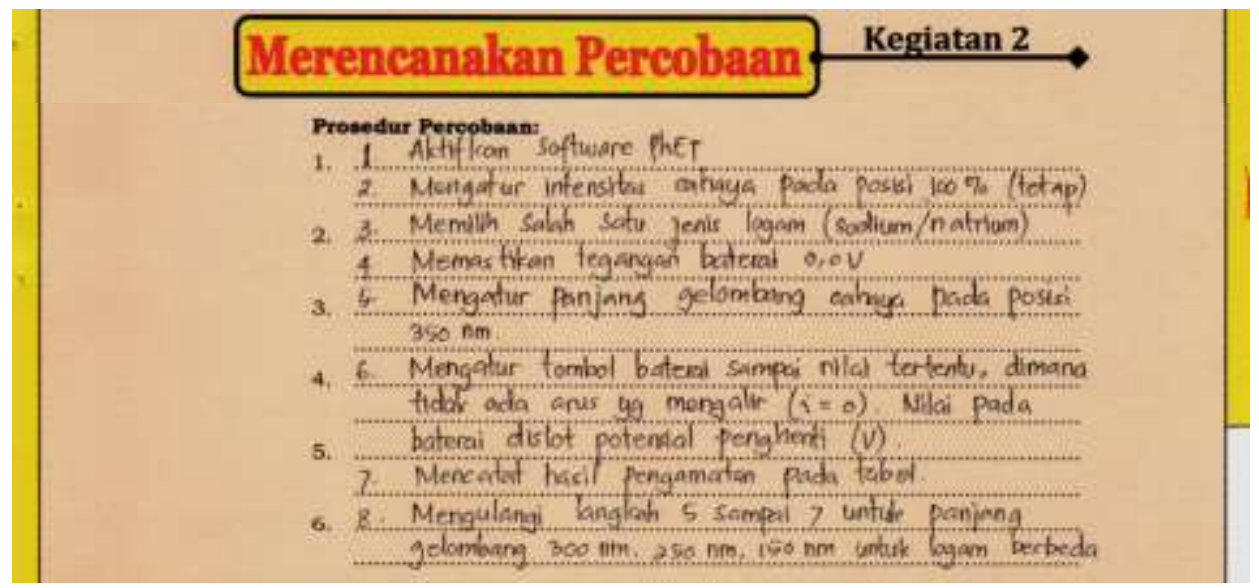

Figure 2. The Example of One of the Experimental Groups' Results in the Planning Experiment Activity.

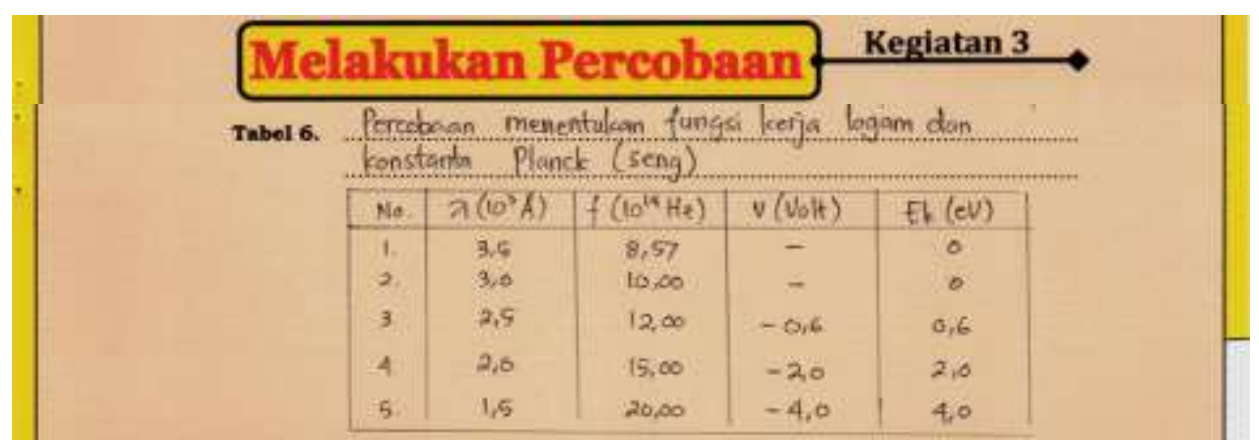

Figure 3. The Example of One of the Experimental Groups' Results in the Experimenting Activity. 


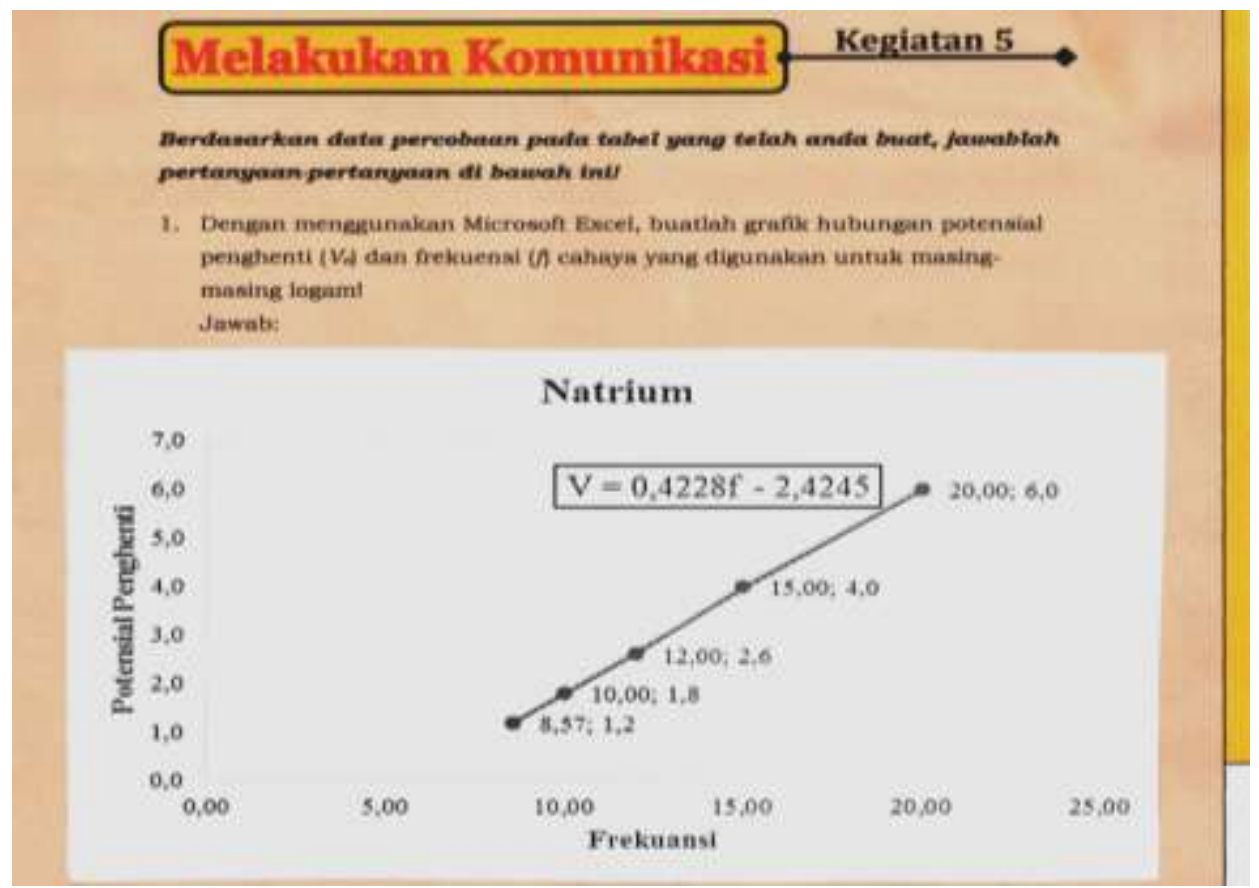

Figure 4. The Example of One of the Experimental Groups' Results in the Communicating Activity.

From the experimental activities conducted using PhET, we can see the formation of students' science process skills for each indicator, as in table 1 below.

Table 1. Achievements of Science Process Skills Each Indicator in Experiments Using PhET

\begin{tabular}{|c|c|}
\hline Science Process Skills Indicators & Achievements of Science Process Skills \\
\hline Predict and hypothesize skill & $\begin{array}{l}\text { Although students are not allowed to open the } \\
\text { notebooks, they can still answer the predictions } \\
\text { based on the photoelectric effect scheme on PhET }\end{array}$ \\
\hline Planning experiment skill & $\begin{array}{l}\text { Students are able to make an experiment } \\
\text { procedure of the photoelectric effect }\end{array}$ \\
\hline Doing the Practicum skill & $\begin{array}{l}\text { Students are able to do the practicum based on the } \\
\text { experiment procedures made and obtained from } \\
\text { the observation data }\end{array}$ \\
\hline Interpreting observation skill & $\begin{array}{l}\text { Students are able to perform data analysis based } \\
\text { on existing questions, so that the students can } \\
\text { master the event's concepts of the photoelectric } \\
\text { effect }\end{array}$ \\
\hline Communicating skill & $\begin{array}{l}\text { Students are able to: make a relationship graphic } \\
\text { of the potential stopper (Vo) and the frequency (f) } \\
\text { of a light used, calculate Planck's constant (h) and } \\
\text { metal work function (W) used on the graphic, and } \\
\text { calculate the error rate of each experiment. }\end{array}$ \\
\hline
\end{tabular}


After doing the experimental class and control class were subjected to different treatment, the experimental class used the student worksheet of development result while the control class with usual learning, the students given post test which aimed to know the students' science process skills improvement in the photoelectric effect material. Based on figure 1, it found that the average post test value for the experimental class and control class are 81.58 and 64.32 respectively. The difference test results show that there is a significant difference between the average post test grade of the experimental class and the control class. The students' learning achievement of the experimental class is higher than the control class. The use of technology PhET is more productive than traditional methods such as lectures and demonstrations [7]. The student worksheet makes students more active and usually improves their success [14].

The result of average analysis of the $\mathrm{N}$-gain value of science process skills of experimental class and control class shown in figure 5 below.

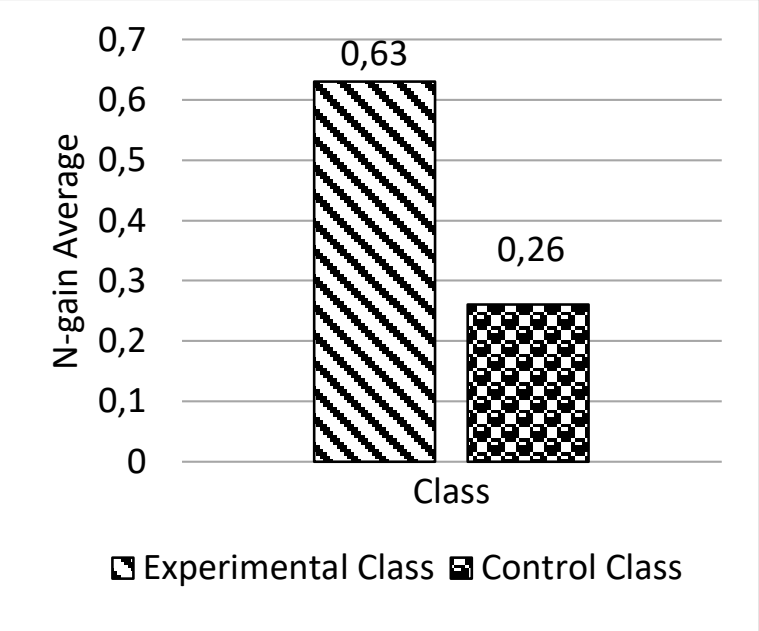

Figure 5. Shows the graphic of average Science Process Skills N-gain Ratio of Experimental Class and Control Class.

Figure 5 shows the average $\mathrm{N}$-gain are 0.63 with medium category and 0.26 with poor category. Interactive multimedia usage is tidies than usual learning [9]. By using interactive multimedia significantly, we can improve students' prestige and problemsolving skills in environmental science [15]. After using the digital learning media, there will be a significant raising of students' prestige [16]. Virtual Lab acts as a supporting factor to enrich experiences and motivate the students to experiment interactively and develop experimenting skills activity [17]. Virtual Lab enables the students to visualize and interact with the phenomena they find in the real lab [18]. Effectiveness refers to the level that operationally the student worksheet can give a result according to what we expected and consistent with the aimed purpose [19].

The improvement of science process skills in this experiment is also occurring in its indicators. Description of data of science process skills of students in table 2 below. 
Table 2. N-gain Average of Each Indicator

\begin{tabular}{lllll}
\hline & \multicolumn{2}{l}{ Experimental Class } & \multicolumn{2}{l}{ Control Class } \\
\cline { 2 - 5 } Indicator of Science Process Skills & N-gain & Criteria & $\begin{array}{l}\text { N- } \\
\text { gain }\end{array}$ & Criteria \\
\hline Predicting and hypothesizing skill & 0,64 & Medium & 0,54 & Medium \\
Planning experiment skill & 0,39 & Medium & $-0,10$ & Low \\
Experimenting skill & 0,54 & Medium & 0,39 & Medium \\
Interpreting observation skill & 0,70 & High & 0,47 & Medium \\
Communicating skill & 0,80 & High & $-0,30$ & Low \\
\hline
\end{tabular}

Based on Table 2, student's science process skills in the experimental class have a higher improvement for each tested indicator. It occurs on the communicating skill as much as 0.80 with the "High" criteria, while in the control class occurs on the predicting and hypothesizing indicator as much as 0.54 with the "Medium".

While the results of the attractiveness, difficulty, and usefulness tests based on the questionnaire given to students can be seen in table 3 below.

Table 3. Result of the Student Worksheet's Attractiveness, Difficulty, and Usefulness Tests of Development Result

\begin{tabular}{llll}
\hline Type of Test & Score & Percentage Score & Criteria \\
\hline Attractiveness & 3,27 & $81,74 \%$ & Interesting \\
Difficulty & 3,25 & $81,32 \%$ & Simple \\
Usefulness & 3,21 & $80,13 \%$ & Useful \\
\hline
\end{tabular}

The attractiveness of the student worksheet of development result assessing from the aspect of display and content has average score 3.27 or if converted to $81.74 \%$ with the "interesting" category. Learning uses student worksheet as an effort to grow students' interest and sympathy in physics subject, in this case, is the interesting student worksheet [20]. The difficulty of the student worksheet of development result assessing from the content and grammatical aspects used, has an average score of 3.25 or if converted to $81.32 \%$ with the "simple" category. The difficulty refers to the level that the result of the student worksheet is useful in learning well [19]. The function of the student worksheet in learning is to be able to facilitate the learner to understand the given material [8]. The usefulness of student worksheet of development result assessing the function has average score 3.21 or if converted to $80.13 \%$ with the "useful" category. The student worksheet can improve student's performance. The expected one is the student's scientific work [21].

\section{Conclusion}

Based on the results of the study and discussion, we can conclude as follows: (1) The student worksheet which building the science process skills on photoelectric effect should include predicting and hypothesizing activities, planning experiments, 
practicum, interpreting observations, and communicating. (2) The student worksheet of development result has an attractiveness level with average score 3.27 or $81.74 \%$ with the "interesting" category, difficulty level with average score 3.25 or $81.32 \%$ with the "simple" category, and usefulness level with average score 3.21 or $80.13 \%$ with the "useful" category. (3) The student worksheet of development result is declared effective to improve the result of student's learning in the form of science process skills with average $\mathrm{N}$-gain equal to 0.63 with the medium category.

\section{References}

[1] Chodijah, S., A. Fauzi, \& R. Wulan. 2012. Development of Physical Learning Tool Using Guided Inquiry Model Equipped with Portofolio Assessment on Circular Motion Material. Jurnal Penelitian Pembelajaran Fisika, 1(2012), 119, ISSN: 2252-3014.

[2] Ozmen, H. \& Yildirim, N. 2002. Effect of Worksheet on Student Succes: Acids and Bases Sample. Journal of Turkish Science Education, 2(2): 10-11.

[3] Ahliswiwite. 2007. Web Based Student Worksheet. Accessed February 7th, 2015, from www. wordpress.com: http://ahliswiwite .files.wordpress.com.

[4] Prastowo, A. 2012. Creative Guide Creating Innovative Instructional Materials. Yogyakarta: Diva Press.

[5] Yenilmez, K. \& M. Ersoy. 2008. Opinions of Mathematics Teacher Candidates Towards Applying 7e Instructional Model on Computer Aided Instruction Environments. International Journal of Instruction. Vol. 1, p. 49 - 60.

[6] Wiyono, K., A. Setiawan, \& A. Suhandi. 2009. Interactive Multimedia Learning Model Special Relativity to Improve Generic Science Skills High School Students. Research Journal of Science Education, III(1), 21-30, ISSN: 19787987.

[7] Finkelstein, N., W. Adams, C. Keller, K. Perkins, \& C. Wieman. 2006. High-Tech Tools for Teaching Physics: the Physics Education Technology Project. Journal of Online Teaching and Learning, Vol. 2, p. 110-121

[8] Rahayu, E., H. Susanto, \& D. Yulianti. 2011. Learning Science with a Process Skill Approach to Improve Student Learning Outcomes and Student Creative Thinking Skills Jurnal Pendidikan Fisika, 7(2011), 106-110, ISSN: 1693-1246.

[9] Utami, I.T. \& A. Arief. 2016. Development of Student Worksheet (LKS) with PhET Virtual Laboratory on Theory of Gas Kinetic Theory Class XI SMA Negeri 2 Sumenep. Jurnal Inovasi Pendidikan Fisika (JIPF), 5(2): 99-105, ISSN: $2302-4496$.

[10] Sugiyono. 2009. Educational Research Methods (Quantitative Approach, Qualitative, and $R \& D$ ).Bandung: Alfabeta.

[11] Hake, R.R. 1999. Interactive-engagement Vs traditional methods: A six thousand student survey of mechanics test data for introductory physics courses. American Journal of Physics, Vol. 66, p. 64-74

[12] Ambarsari, W., S. Santosa, \& Maridi. 2013. Implementation of Guided Inquiry 
Learning on the Basic Science Process Skills in Biology Lesson of Eight Grade Class of SMP Negeri 7 Surakarta. Jurnal Pendidikan Biologi, 5(1), 81-95.

[13] Lee, A.T., R.V. Hairston, R. Thames, T. Lawrence, \& S.S. Herron. 2002. Using a Computer Simulation to Teach Science Process Skills to College Biology and Elementary Education Majors. Department of Biological Sciences University of Southern Mississippi, Vol. 28, p. 35-42.

[14] Töman U, Akdeniz A. R, Gurbuz F., \& Odabasi Cimer S. 2012. Extended Worksheet Developed According to 5E Model Based on Constructivist Learning Approach, International Journal on New Trends in Education and Their Implications, 4(16) 1309-6249

[15] Frear, V., \& Hirschbuhl, J. J. 1999. Does interactive multimedia promote achievement and higher level thinking skills for today's science students?. British Journal of Educational Technology, 30(4), 323-329.

[16] Praneetham, C., \& Thathong, K. 2016. Development of Digital Instruction for Environment for Global Warming Alleviation. Turkish Online Journal of Educational Technology, 15(2).

[17] Tatli, Z. \& Ayas, A. 2012. Virtual Chemistry Laboratory. Turkish Online Journal of Distance Education, 13(1): 83-199.

[18] Marti'nez, G., Francisco, L., Naranjo, A’ngel, L., Pe'rez, Suero, M. I., \& Pardo, P. J. 2011. Comparative Study of The Effectiveness of Three Learning Environments: Hyperrealistic Virtual Simulations, Traditional Schematic Simulations, and Traditional Laboratory. Physics Education Research, (Online), 7 (2): (http://www.aahperd.org) Accessed Juni 19th, 2017

[19] Akker, J., Branch, R.M., Gustafson, K., Nieveen, N., \& Plomp, T. 1999. Design Approaches and Tools in Education and Training. London: Kluwer Academic Publishers.

[20] Kaltakci, D. \& O. Oktay. 2011. A Guided-Inquiry Laboratory Experiment to Reveal Students'Comprehension of Friction Concept: A Qualitative study. Balkan Phys. Letters, 19, 180-190.

[21] Arafah, S. F., Bambang P., \& Saiful R. 2012. Development of Student Worksheet Based on Critical Thinking on Animalia Material. Unnes Journal of Biology Education (UJBE), 1(1): 75-81. 